\title{
CHARACTERIZATION AND ANTIBACTERIAL ACTIVITY OF SILVER NANOPARTICLES BIOSYNTHESIZED USING (INDIGOFERA OBLONGIFOLIA) LEAVES EXTRACT
}

\author{
SALMEN, S. H. ${ }^{*}$ - AlwhiBI, M. S. - AlHARBI, S. A. \\ Department of Botany and Microbiology, College of Science, King Saud University, P. O. Box \\ 2455, Riyadh 11451, Saudi Arabia \\ *Corresponding author \\ e-mail:ssalmen@ksu.eda.sa \\ (Received $13^{\text {th }}$ May 2019; accepted $28^{\text {th }}$ Aug 2019)
}

\begin{abstract}
Here, we describe the novel biosynthesis of silver nanoparticles (AgNPs) using the extract of Indigofera oblongifolia (Hasr) leaves. The synthesized AgNPs were confirmed and characterized using ultraviolet-visible spectrophotometry, Fourier transform infrared spectroscopy (FTIR), energy dispersive spectroscopy (EDS), scanning electron microscopy (SEM), and transmission electron microscopy (TEM). An extreme absorption was detected at a wavelength near $400 \mathrm{~nm}$ after the formation of AgNPs. FTIR determined the extract biomolecules responsible for the reduction of the synthesized AgNPs. An EDS signal at $3 \mathrm{keV}$ confirmed the presence of the Ag signal using surface plasmon resonance. SEM and TEM revealed the generally circular shape of AgNPs with sizes ranging from $8 \mathrm{~nm}$ to $25 \mathrm{~nm}$ (average particle size $15 \mathrm{~nm}$ ). The antibacterial activity of AgNPs was pronounced for all bacteria studied.
\end{abstract}

Keywords: nanoparticles, I. oblongifolia, biosynthesis, bacteria, biotechnology

\section{Introduction}

Nanoparticles (NPs) play significant roles in biotechnology and pharmaceutical industries (Vijayakumar et al., 2013). The physical, biological, and chemical characterization of manufactured NPs is one of the fastest growing areas of science. The biosynthesis of NPs using plants (Peter et al., 2013, 2015; Deenadayalan et al., 2014), bacteria (Husseiny et al., 2006; El-Shanshoury et al., 2011), and fungi (Ingle et al., 2009; Neveen-Mohamed, 2014) has been described.

Interest has grown concerning the use of silver (Ag) NPs, which are inexpensive, safe, and ecologically-friendly. Recent studies have successfully biosynthesized AgNPs using plant components including the Eriobotrya japonica (Thunb.) leaf extract (Yu et al., 2019), cowpea (Vigna sp. L) seed extract (Mohammadi et al., 2016), Pandanus odorifer leaf extract (Hussain et al., 2019), Ribes nigrum fruit extract (Dobrucka et al., 2018), Rosmarinus officinalis leaf extract (Ghaedi et al., 2015), Terminaliachebula leaf extract (Chandra et al., 2016), and Diospyros paniculata root extract (Hanumanta et al., 2016). Indigofera oblongifolia is a perennial shrub that belongs to the family Fabaceae. It grows throughout Asia and Africa (Abdel and Ahmed, 2016). It is commonly known as Hasr in the South of Saudi Arabia and Yemen. As a traditional medicine, the leaves of this plant are used to treat some diseases due to their analgesic and anti-inflammatory activities. Moreover, in Saudi Arabia, I. oblongifolia is cultured in regions with a high occurrence of malaria, such as Nagran and Jazan (Nzila, 2013). The plant contains indigoferic acid and indigin as the fatty acid esters of hydroxy (E)-cinnamic acid and alkylated xanthenes, respectively, and also 3-hydroxybenzoic acid and $\beta$-sitosterol (Sharif et al., 2005). 
To our knowledge, this is the first study to examine the use of the extract of $I$. oblongifolia (Hasr) leaves for the biosynthesis of AgNPs. AgNPs biosynthesized as such were characterized using different physical techniques that included ultraviolet (UV)visible spectrophotometry, Fourier transform infrared (FTIR) spectroscopy, energy dispersive X-ray spectroscopy (EDS), scanning electron microscopy (SEM), and transmission electron microscopy (TEM). Finally, the antibacterial activity of the biosynthesized NPs against select gram-negative and gram-positive bacteria was studied.

\section{Materials and methods}

\section{Plant material and preparation of extract}

I. oblongifolia leaves were collected from Shabwah, South of Yemen. The plant was verified by the staff of the Herbarium, Department of Botany and Microbiology, King Saud University. Fresh leaves of I. oblongifolia were rinsed thoroughly numerous times using distilled water and allowed to completely air-dry in the dark. The powder prepared from the dried leaves $(10 \mathrm{~g})$ was placed in $100 \mathrm{~mL}$ deionized water and boiled for $10 \mathrm{~min}$ with stirring. The liquid extract was filtered using Whatman No. 1 filter paper. The residual extract was stored at $4{ }^{\circ} \mathrm{C}$ until processed.

\section{Biosynthesis of AgNPs}

Ten milliliters of the aqueous plant extract was mixed with $100 \mathrm{~mL}$ of $0.01 \mathrm{mM}$ aqueous solution of silver nitrate $\left(\mathrm{AgNO}_{3}\right)$ with constantly stirring for $5 \mathrm{~min}$ at $25^{\circ} \mathrm{C}$. The resulting mixture was maintained undisturbed until the neutral solution changed to a brown color. Then, the molecules were by centrifugation at 13,000 rpm for $20 \mathrm{~min}$. Finally, the obtained AgNPs were dried in oven at $40{ }^{\circ} \mathrm{C}$ for $2 \mathrm{~h}$ prior to characterization of AgNPs.

\section{Characterization of AgNPs}

\section{UV-Visible spectroscopy}

The formation of AgNPs in suspension was monitored using UV-Visible spectroscopy of the solution at wavelengths ranging from 300 to $800 \mathrm{~nm}$ using an Ultrospec 2100 Pro UV/visible spectrophotometer (Biochrom, UK).

\section{FTIR spectroscopy}

FTIR spectroscopy was performed to screen for functional groups in the phytoconstituents in the synthesized AgNPs and aqueous extract of I. oblongifolia. FTIR spectra were obtained by scanning from 400 to $4,000 \mathrm{~cm}^{-1}$.

\section{SEM and EDS}

SEM used a model JSM-6380 LA microscope (JEOL, Japan). EDS was done using an Altima IV device (Regaku, Japan).

\section{TEM}

TEM examination of AgNP size, shape, and morphology was performed using a JEM1011 microscope (JEOL). 


\section{Antibacterial studies}

\section{Bacteria}

The bacteria were obtained from the Microbiology Laboratory of the College of Science, King Saud University. The gram-positive bacteria examined were Staphylococcus aureus (29213 ATCC), Bacillus subtilis, and Streptococcus pyogenes. The gram-negative bacteria examined were Escherichia coli (25922 ATCC) and Salmonella typhimurium (14028 ATCC). All bacteria were inoculated on nutrient agar (Sigma-Aldrich, Munich, Germany) and incubated at $37^{\circ} \mathrm{C}$ for $24 \mathrm{~h}$.

\section{Antibacterial activities}

The antibacterial activity of the synthesized AgNPs was studied using the agar well diffusion technique (Valodkar et al., 2011). Petri plates containing $20 \mathrm{ml}$ Mueller Hinton Agar medium (Sigma-Aldrich) were inoculated with each bacterium to obtain a lawn of growth. Wells $6 \mathrm{~mm}$ in diameter were cut into the medium using a sterile agar borer. Then, synthesized nanoparticles $(100 \mu \mathrm{l})$ were added to each well, and the plates were incubated at $37{ }^{\circ} \mathrm{C}$ for $24 \mathrm{~h}$. Inhibition of growth was evident as a clear zone around the well. The control used was distilled water.

\section{Statistical analysis}

The results of antibacterial activity were expressed as the mean \pm standard deviation (SD), and all experiments were performed in triplicate. The statistical results were calculated by one-way analysis using the SPSS statistical software (SPSS Inc., USA), A $\mathrm{P}$-value $<0.05$ indicated statistical significance.

\section{Results and discussion}

\section{Biosynthesis of AgNPs and their visible spectrum}

Immediately after mixing the I. oblongifolia extract with an $\mathrm{AgNO}_{3}$ solution, a dark brown color developed. The color change indicated the formation of AgNPs, which was confirmed by the UV-Visible absorption spectrum (Fig. 1). UV-Visible spectroscopy has been used to investigate the shape and size of AgNPs in aqueous solution (Ranjit et al., 2013) and provided primary evidence for the formation of AgNPs (Nanda and Saravanan, 2013). Presently, the biosynthesized mixture was evaluated at wavelengths ranging from 200 to $800 \mathrm{~nm}$; the highest peak absorption was observed at $400 \mathrm{~nm}$ as a result of AgNP formation.

\section{FTIR}

FTIR was used to confirm the presence of biocompounds in the extract of $I$. oblongifolia that were responsible for the formation of AgNPs. Figure $2 A$ and $B$ depict the FTIR spectra of the I. oblongifolia extract and AgNPs. The extreme band at $3,413 \mathrm{~cm}^{-1}$ in the I. oblongifolia extract was attributed to the $\mathrm{O}-\mathrm{H}$ stretching band of phenols and alcohols (Preeti and Mausumi, 2013), which shifted to 3,433 $\mathrm{cm}^{-1}$ after reduction of the synthesized AgNPs as a result of protein binding. The other bands at 2917 and $1448 \mathrm{~cm}^{-1}$ in I. oblongifolia extract corresponded to $\mathrm{C}-\mathrm{H}$ (alkane) and C-N (aromatic amines), respectively, which were absent from the FTIR spectrum of AgNPs. A second intense peak was observed at $1,614 \mathrm{~cm}^{-1}$ in the I. oblongifolia extract. It 
changed to $1596 \mathrm{~cm}^{-1}$ with the formation of AgNPs, signifying the presence of carbonyl $(\mathrm{C}-\mathrm{O})$ stretching vibrations. The findings indicate that effective groups like phenols, alcohols, alkane, and aromatic amines present in the extract of I. oblongifolia may be responsible for the bioreduction of silver into AgNPs.

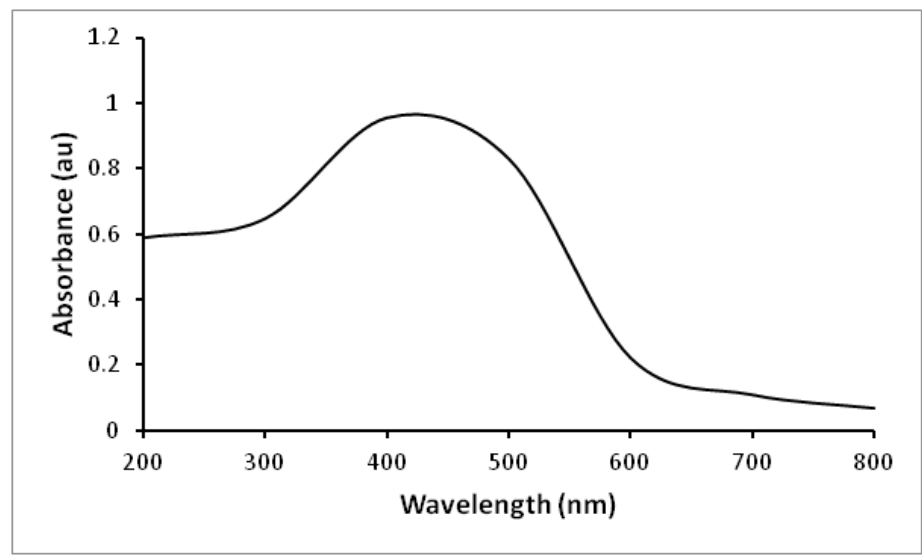

Figure 1. UV-Visible spectrum for the reaction of the I. oblongifolia extract with the $\mathrm{AgNO}_{3}$ solution
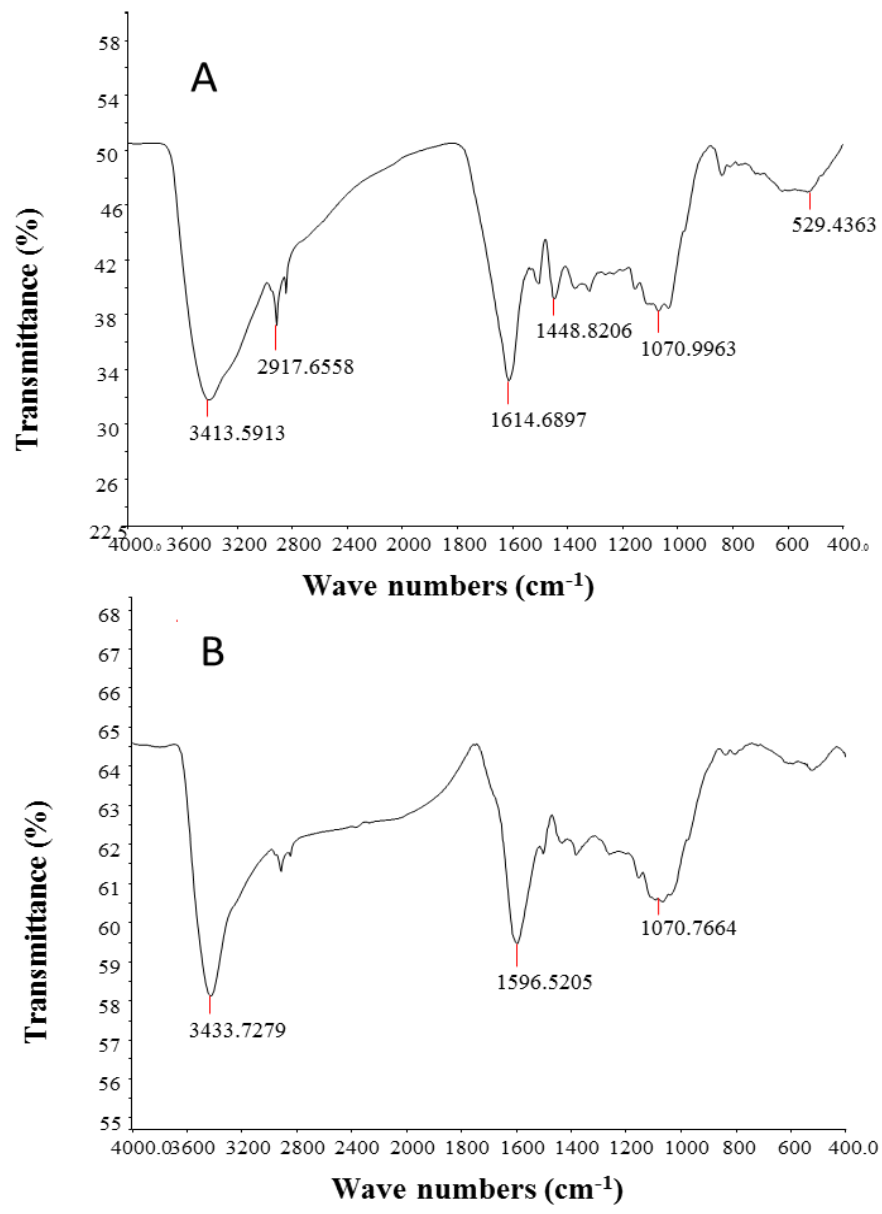

Figure 2. FTIR spectra of the I. oblongifolia extract (A) and AgNPs produced using the I. oblongifolia leaf extract $(B)$ 


\section{SEM and EDS analyses}

SEM of the biosynthesized AgNPs revealed various sizes of the irregularly formed AgNPs (Fig. 3). Clusters of AgNPs were evident in some images, which can be associated with the aggregation of NPs during the sample synthesis. The EDS spectra of AgNPs for study of elemental composition of the silver particles are presented in Figure 3 and displayed strong signals in the silver region at $3 \mathrm{keV}$. An exemplary absorption peak of AgNPs at approximately $3 \mathrm{keV}$ was reported using surface plasmon resonance (Nadagouda et al., 2011; Khan et al., 2014). EDS analysis revealed the existence of silver (68.94\%). The appearance of chlorine and oxygen signals in the image may be due to X-ray emissions from the proteins present in the plant extract.

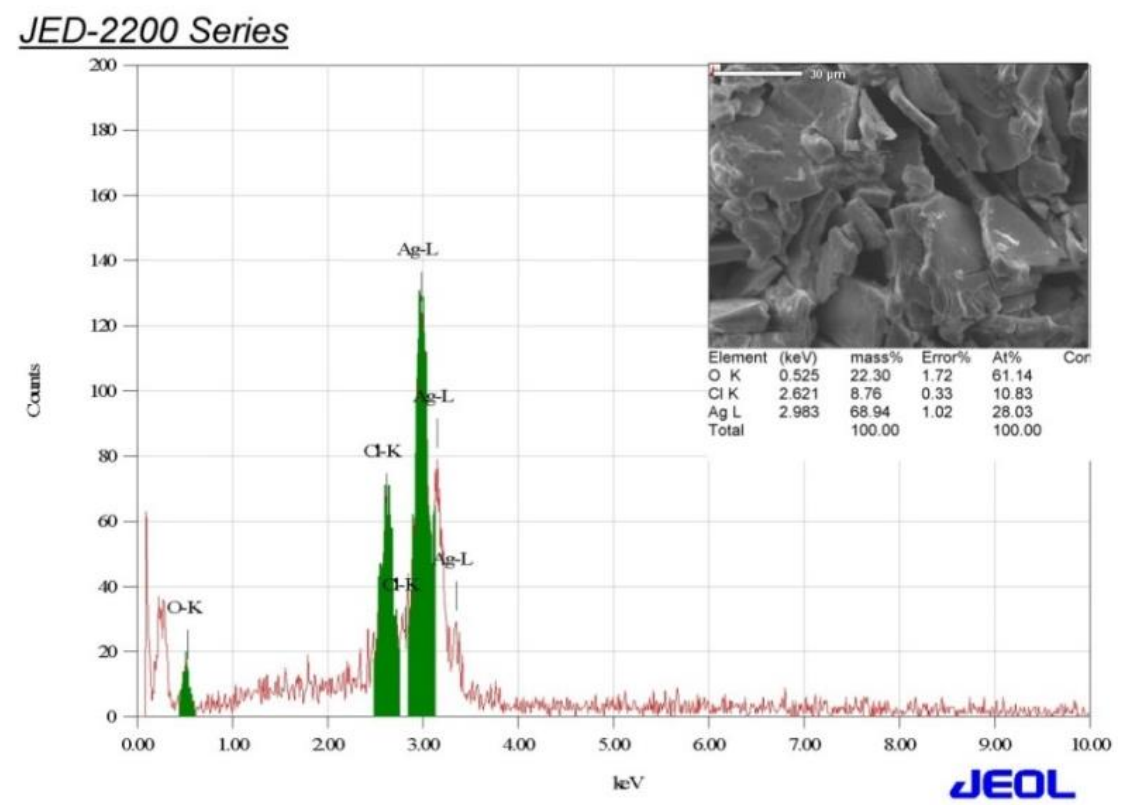

Figure 3. SEM image and EDS of AgNPs synthesized using I. oblongifolia leaf extract

\section{TEM}

TEM was performed to observe the morphology and sizes of the AgNPs. A representative image is presented in Figure 4. The AgNPs were extremely stable, smooth, and circular. The NPs ranged in size from $8 \mathrm{~nm}$ to $25 \mathrm{~nm}$ with an average particle size of $15 \mathrm{~nm}$. No accumulation of AgNPs was observed.

\section{Antibacterial activity}

The growth inhibition caused by the AgNPs biosynthesized using the I. oblongifolia extract against representative gram-positive and -negative bacteria are presented in Table 1. The growth of all the bacteria was impeded, however, E. coli and B. subtilis were most sensitive to the inhibitory effect of the AgNPs, showing larger zones of growth inhibition compared to those of $S$. aureus, S. typhimurium, and S. pyogenes. As anticipated, growth was not inhibited for the control. These findings are consistent with those of other studies demonstrating the preparation of AgNPs with potent antibacterial and anti-fungal activities using plants extracts (Puiso et al., 2014; Ismail et al, 2017; Khalil et al., 2017; Matinise, et al., 2018; Premkumara et al,. 2018). 


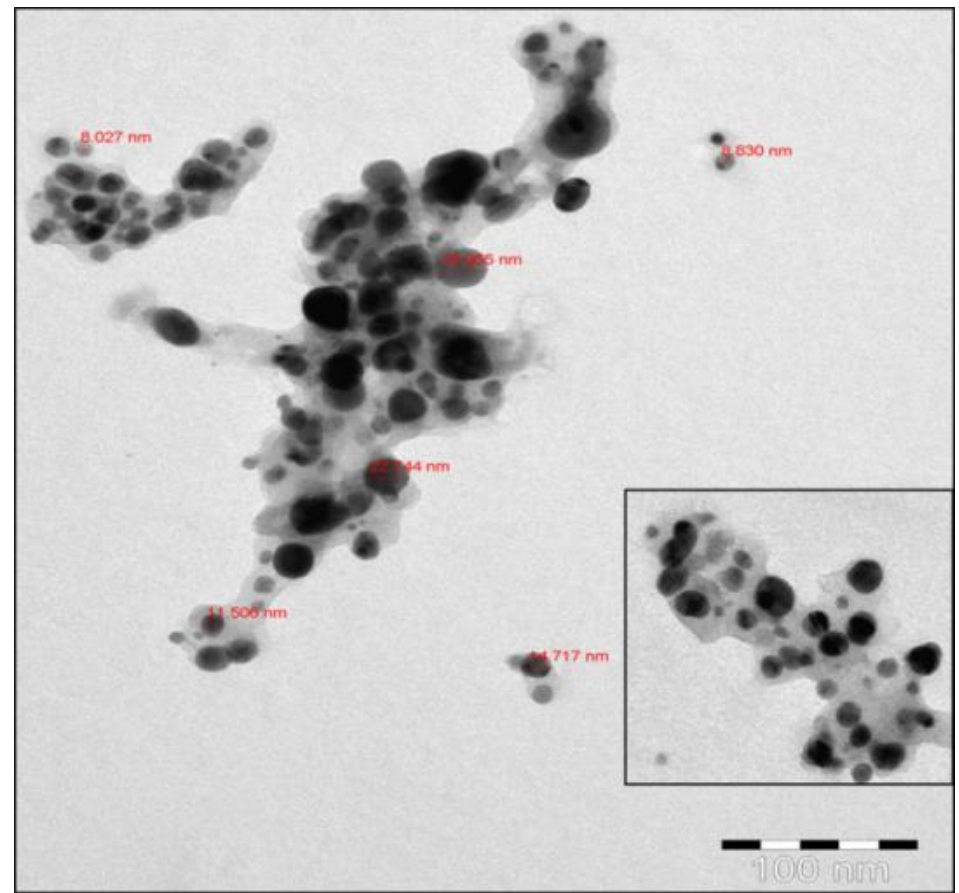

Figure 4. TEM image of AgNPs synthesized using I. oblongifolia leaf extract

Table 1. Antibacterial activity of silver nanoparticles (AgNPs) against representative grampositive and gram-negative bacteria

\begin{tabular}{c|c|c}
\hline \multirow{2}{*}{ Name of bacteria } & \multicolumn{2}{|c}{ Inhibition zone (mm) } \\
\cline { 2 - 3 } & AgNPs & Control \\
\hline Staphylococcus aureus & $13.5 \pm 0.5^{*}$ & $0 \pm 0.0$ \\
Bacillus subtilis & $15.3 \pm 0.5$ & $0 \pm 0.0$ \\
Streptococcus pyogenes & $11 \pm 0.0$ & $0 \pm 0.0$ \\
Escherichia coli & $17 \pm 1.15$ & $0 \pm 0.0$ \\
Salmonella typhimurium & $13 \pm 0.0$ & $0 \pm 0.0$ \\
\hline
\end{tabular}

$*$ Results are shown as mean \pm SD

\section{Conclusions}

This is the first description of the biosynthesis of AgNPs using the extract of $I$. oblongifolia leaves. The method is rapid, simple, eco-friendly, and safe. UV-Visible spectrophotometry, FTIR spectroscopy, EDS, SEM, and TEM confirmed the production of AgNPs. The success of the I. oblongifolia leaf extract to synthesize AgNPs is very promising for the eco-friendly and sustainable production of nanomaterials. The potency of the antibacterial activity of the AgNPs synthesized in this study was evident, and the results of this study are in agreement with those of other recent studies regarding the use of plant extracts for the synthesis of nanoparticles.

Acknowledgments. This project was supported by Researchers Supporting Project number (RSP-2019/5) King Saud University, Riyadh, Saudi Arabia. 


\section{REFERENCES}

[1] Abdel, M., Ahmed, E. (2016): Indigofera oblongifolia prevents lead acetate-induced hepatotoxicity, oxidative stress, fibrosis and apoptosis in rats. - PloS One 11(7): 1-18.

[2] Chandra, S. E., Krishna Rao, K. V., Madhusudana Rao, K. (2016): Bio-synthesis and characterization of silver nanoparticles using Terminalia chebula leaf extract and evaluation of its antimicrobial potential. - Mater. Let. 174: 129-133.

[3] Deenadayalan, A. K., Palanichamy, V., Selvaraj, M. R. (2014): Green synthesis of silver nanoparticles using Alternanthera dentata leaf extract at room temperature and their antimicrobial activity. - Spectrochimica Acta Part A. 127: 168-171.

[4] Dobrucka, R., Kaczmarek, M., Dlugaszewska, J. (2018): Cytotoxic and antimicrobial effect of biosynthesized silver nanoparticles using the fruit extract of Ribes nigrum. Adv. Nat. Sci. Nanosci. Nanotechnol. 9: 025015.

[5] El-Shanshoury, A. E. R., El Silk, S. E., Ebeid, M. E. (2011): Extracellular biosynthesis of silver nanoparticles using Escherichia coli ATCC 8739, Bacillus subtilis ATCC 6633, and Streptococcus thermophilus ESh1 and their antimicrobial activities. - ISRN Nanotechnol. \#385480. http://dx.doi.org/10.5402/2011/385480.

[6] Ghaedi, M., Yousefinejad, M., Safarpoor, M., Khafria, H.Z, Purkaitc, M. K. (2015): Rosmarinus officinalis leaf extract mediated green synthesis of silver nanoparticles and investigation of its antimicrobial properties. - J. Industr. Eng. Chem. 31: 167-172.

[7] Hanumanta Rao, N., Lakshmidevi, N., Pammi, S. N., Kollu, P., Ganapaty, S., Lakshmi, P. (2016): Green synthesis of silver nanoparticles using methanolic root extracts of Diospyros paniculata and their antimicrobial activities. - Mater. Sci. Eng. C. 62: 553557.

[8] Hussain, A., Alajmi, M. F., Khan, M. A., Pervez, S. A., Ahmed, F, Amir. S., Husain, F. M., Khan, M. S., Shaik, G. M., Hassan, I, Rais, A., Khanand Md. Rehman, T. (2019): Biosynthesized silver nanoparticle (AgNP) from Pandanus odorifer leaf extract exhibits anti-metastasis and anti-biofilm potentials. - Front. Microbiol. 10: 8.

[9] Husseiny, M. I., Aziz, M. A. E., Badr, Y., Mahmoud, M. A. (2006): Biosynthesis of gold nanoparticles using Pseudomonas aeruginosa. - Spectrochim Acta Part A. 67: 10031006.

[10] Ingle, A., Rai, M., Gade, A., Bawaskar, M. (2009): Fusarium solani: a novel biological agent for the extracellular synthesis of silver nanoparticles. - J. Nanoparticle Res. 11: 2079-2085.

[11] Ismail, E., Khenfouch, M., Dhlamini, M., Dube, S., Maaza, M. (2017): Green palladium and palladium oxide nanoparticles synthesized via Aspalathus linearis natural extract. - J. Alloys Comp. 695: 3632-3638.

[12] Khalil, T. A., Ovais, M., Ullah, I., Ali, M., Shinwari, Z. K., Maaza, M. (2017): Physical properties, biological applications and biocompatibility studies on biosynthesized single phase cobalt oxide $\left(\mathrm{CO}_{3} \mathrm{O}_{4}\right)$ nanoparticles via Sageretia thea (Osbeck). - Arabian J. Chem. http://dx.doi.org/10.1016/j.arabjc.2017.07.

[13] Khan, M., Khan, S. T., Khan, M., Adil, S. F., Musarrat, J., Al-Khedhairy, A. A., AlWarthan, A., Siddiqui, M. R., Alkhathlan, H. Z. (2014): Antibacterial properties of silver nanoparticles synthesized using Pulicaria glutinosa plant extract as a green bioreductant. - Int. J. Nanomed. 9: 3551-3565.

[14] Matinise, N., Kaviyarasu, K., Mongwaketsi, N., Khamlich, S., Maaza, M. (2018): Green synthesis of novel zinc iron oxide $\left(\mathrm{ZnFe}_{2} \mathrm{O}_{4}\right)$ nanocomposite via Moringa oleifera natural extract for electrochemical applications. - Appl. Surf. Sci. 446: 66-73.

[15] Mohammadi, S., Pourseyedi, S., Amini, A. (2016): Green synthesis of silver nanoparticles with a long lasting stability using colloidal solution of cowpea seeds (Vigna sp. L). - J. Environ. Chem. Engin. 4: 2023-2032.

[16] Nadagouda, M. N., Speth, T. F., Varma, R. S. (2011): Microwave-assisted green synthesis of silver nanostructures. - Acc. Chem. Res. 44(7): 469-478. 
[17] Nanda, A., Saravanan, M. (2013): Biosynthesis of silver nanoparticles from Staphylococcus aureus and its antimicrobial activity against MRSA and MRSE. Nanomed. Nanotechnol. Biol. Med. 1: 452-456.

[18] Neveen-Mohamed, K. (2014): Biogenic silver nanoparticles by Aspergillus terreus as a powerful nanoweapon against Aspergillus fumigates. - Afr. J. Microbiol. Res. 7: 56455651.

[19] Nzila, A., Al-Zahrani, I. (2013): Drugs for the treatment of malaria in the Kingdom of Saudi Arabia. - Saudi Med. J. 34: 569-578.

[20] Peter, L., Silambarasan, S., Abraham, J. (2013): Ecofriendly synthesis of silver nanoparticles from commercially available plant powders and their antibacterial properties. - Scientia Iranica 20: 1049-1054.

[21] Peter, L., Sivagnanam, S., Abraham, J. (2015): Synthesis of silver nanoparticles using plants extract and analysis of their antimicrobial property. - J. Saudi. Chem. Soc. 19: 311-317.

[22] Preeti, D., Mausumi, M. (2013): In-vitro free radical scavenging activity of biosynthesized gold and silver nanoparticles using Prunus armeniaca (apricot) fruit extract. - J. Nanopart. Res. 15(1): 1366.

[23] Premkumara, J., Sudhakara, T., Dhakala, A., Shresthaa, J. B., Krishnakumara, S., Balashanmugamb, P. (2018): Synthesis of silver nanoparticles (AgNPs) from cinnamon against bacterial pathogens. - Biocatal. Agric. Biotechnol. 15: 311-316.

[24] Puiso, J., EJonkuviene, D., Macioniene, I., Salomskiene, J., Jasutiene, I., Kondrotas, R. (2014): Biosynthesis of silver nanoparticles using lingonberry and cranberry juices and their antimicrobial activity. - Colloids Surf. B. Biointerfaces 121: 214-221.

[25] Ranjit, K, Baquee, A. A. (2013): Nanoparticle: an overview of preparation, characterization and application. - Int. Res. J. Pharm. 4: 4-9.

[26] Sharif, A., Ahmed, E., Malik, A., Riaz, N., Afza, N., Nawaz, S. A., Arshad, M., Shah, M. R., Choudhary M. I. (2005): Lipoxygenase inhibitory constituents from Indigofera oblongifolia. - Arch. Pharm. Res. 28: 761-764.

[27] Valodkar, M., Nagar, P. S., Jadeja, R. N., Thounaojam, M. C., Devkar, R. V., Thakore, S. (2011): Euphorbiaceae latex induced green synthesis of non-cytotoxic metallic nanoparticle solutions: a rational approach to antimicrobial applications. - Colloids Surf. A. Physicochem. Eng. Asp. 384: 337-344.

[28] Vijayakumar, M., Priya, K., Nancy, F. T., Noorlidaha, A., Ahmeda, A. B. A. (2013): Biosynthesis, characterization and anti-bacterial effect of plant-mediated silver nanoparticles using Artemisia nilagirica. - Ind. Crops Prod. 41: 235-240.

[29] Yu, C., Tang, J., Liu, X., Ren, X., Zhen, M., Wang, L. (2019). Green biosynthesis of silver nanoparticles using Eriobotrya japonica (Thunb.) leaf extract for reductive catalysis. - Materials 12: 189. DOI: 10.3390/ma12010189. 